\title{
Prediction of the Modulus of Elasticity of Eucalyptus grandis Through Two Nondestructive Techniques
}

\author{
Pedro Henrique Gonzalez de Cademartori ${ }^{1}$, André Luiz Missio ${ }^{2}$, \\ Darci Alberto Gatto ${ }^{2,3}$, Rafael Beltrame ${ }^{4}$ \\ ${ }^{1}$ Programa de Pós-Graduação em Engenharia Florestal - PPGEF, Centro de Ciências Florestais e da Madeira, \\ Universidade Federal do Paraná - UFPR, Curitiba/PR, Brasil \\ ${ }^{2}$ Programa de Pós-Graduação em Engenharia Florestal - PPGEF, Centro de Ciências Rurais, \\ Universidade Federal de Santa Maria - UFSM, Santa Maria/RS, Brasil \\ ${ }^{3}$ Programa de Pós-Graduação em Ciências e Engenharia de Materiais - PPGCEM, \\ Centro de Desenvolvimento Tecnológico, Universidade Federal de Pelotas - UFPEL, Pelotas/RS, Brasil \\ ${ }^{4}$ Engenharia Industrial Madeireira, Centro de Engenharias, Universidade Federal de Pelotas - UFPEL, Pelotas/RS, Brasil
}

\begin{abstract}
The present study aimed to estimate the modulus of elasticity (MOE) at static bending of Rose gum (Eucalyptus grandis) heartwood and sapwood through two nondestructive techniques: ultrasound and stress wave. Sixty samples of heartwood and sapwood were prepared. Nondestructive tests were performed using ultrasound and stress wave timer equipment, while destructive tests were carried out in a universal machine through static bending tests. The main results showed that the heartwood presented better behavior than the sapwood in the nondestructive tests. However, the best model was obtained considering both wood types through the ultrasonic technique. Therefore, stress wave and ultrasonic techniques could be employed to estimate the modulus of elasticity of Rose gum wood.
\end{abstract}

Keywords: ultrasound, stress wave, wood technology.

\section{Predição do Módulo de Elasticidade de Eucalyptus grandis Por Meio de Duas Técnicas Não Destrutivas}

\begin{abstract}
RESUMO
O presente estudo objetivou estimar o módulo de elasticidade à flexão estática da madeira de cerne e alburno de Eucalyptus grandis, por meio de duas técnicas não destrutivas: ultrassom e ondas de tensão. Para tal, 60 amostras de cerne e alburno foram preparadas. Os testes não destrutivos foram realizados por meio de um equipamento de ultrassom e um de ondas de tensão, enquanto que os testes destrutivos de flexão estática foram realizados em uma máquina universal de ensaios. Os principais resultados mostraram que a madeira de cerne apresentou melhor comportamento nos ensaios não destrutivos, quando comparada à madeira de alburno. No entanto, o melhor modelo matemático foi obtido considerando-se cerne e alburno, quando estes foram analisados por meio da técnica ultrassônica. Dessa maneira, concluiu-se, no presente estudo, que as técnicas de ondas de tensão e ultrassom podem ser empregadas com o intuito de estimar o módulo de elasticidade da madeira de Eucalyptus grandis.
\end{abstract}

Palavras-chave: ultrassom, ondas de tensão, tecnologia da madeira. 


\section{INTRODUCTION}

Nondestructive materials evaluation is the science of identifying physico-mechanical properties of a piece of material without modifying its characteristics and final application, using this information to make decisions regarding its applications (Ross et al., 1998). The area of nondestructive evaluation (NDE) is in constant evolution, especially in the wood sector (Brashaw et al., 2009); however, wood is an anisotropic and heterogeneous material that hinders evaluation and characterization compared to other materials (Feeney et al., 1998).

The most commonly used NDE techniques are transverse vibration, stress wave, ultrasound (acoustic emission and acoustic ultrasonic emission) (Ross \& Pellerin, 1994); electrical resistance, colorimetry, dielectric properties, and X-rays (Pellerin \& Ross, 2002).

Stress wave propagation in wood is a dynamic process that is directly related to physico-mechanical properties. Generally, stress wave presents better propagation on wood with high sonorous quality than on decayed wood. This technique is employed in order to analyse wood pieces, besides evaluating the internal conditions of trees by measuring the propagation time in radial direction (Wang et al., 2004).

The ultrasonic technique is employed mainly for determination of the elastic constant, which is used to predict the biological modifications in wood structure and evaluate the process of sawing. According to Targa et al. (2005), techniques that employ resonance frequency, ultrasonic velocity and acoustic emission can evaluate structural and functional integrity of many wood products.

Many studies using ultrasonic techniques reported basic information of properties of anisotropic materials. These results present a wide application range, especially in the definition of material properties, which could be used in software simulations to examine the impact of silvicultural practices on wood quality (Brashaw et al., 2009).

Stress wave and ultrasonic techniques are simpler and less expensive than image techniques. Wave propagation is a mechanical phenomenon used to detect internal flaws in wood (Ross \& Pellerin,
1994). Likewise, non-destructive techniques are used mainly to verify how these occurrences affect the physical and mechanical properties of wood (Gonçalez et al., 2001).

Nondestructive techniques have been frequently used to predict the mechanical properties of wood, such as the modulus of elasticity (MOE) (Oliveira et al., 2002; Carrasco \& Azevedo, 2003; Stangerlin et al., 2008; Del Menezzi et al., 2010; Missio et al., 2013a, b).

Nondestructive techniques have many advantages, such as velocity of analyses, low cost, versatility, utilization in live trees, and easy transportation of equipment compared with destructive techniques. The material analyzed is not affected by the phenomenon of propagation; the samples could be tested many times without deformation and could be evaluated in service (Oliveira et al., 2002). These techniques also enable wood maintenance through mapping of decayed areas without the need to remove parts of the structure. In this context, the present study aimed to predict the modulus of elasticity at static bending through ultrasound and stress wave techniques.

\section{MATERIAL AND METHODS}

\subsection{Raw material}

Rose gum (Eucalyptus grandis) trees (17 years old) from a homogeneous population located in the north coast of Rio Grande do Sul state, Southern of Brazil ( $30^{\circ} 14^{\prime} 09.73$ ” S, 50 19' 55.07” O) were harvested, all of them with cylindrical trunk and diameter over $25 \mathrm{~cm}$ at diameter breast height ( $\mathrm{DBH}$, $1.30 \mathrm{~m}$ height).

The first $\log$ (3.15 m length) of each tree was cut. Then, sixty samples of heartwood and sapwood (30 per treatment) measuring $10 \times 10 \times 200 \mathrm{~mm}$ (radial $\times$ tangential $\times$ longitudinal) were prepared, all of them with straight grain and absence of knots. The heartwood and sapwood samples were cut from the region between pith and bark and its distinction was realized by visual analysis of color.

The samples were then placed in climatic chamber at $20{ }^{\circ} \mathrm{C}$ and $65 \%$ relative humidity for stabilization 
of moisture content so that nondestructive and destructive tests could be carried out.

\subsection{Nondestructive tests}

The ultrasonic tests were performed in an ultrasound equipment (Proceq, model TICO) using dry-point transducers (frequency of $54 \mathrm{~Hz}$ ). The time and velocity of wave propagation were measured by direct method. Thus, the elastic constant in ultrasonic tests $\left(\mathrm{ED}_{\mathrm{us}}\right)$ was measured through Equation 1.

$E D_{u s}=\left(V^{2} \cdot \rho_{12 \%}\right) \cdot 10^{-6}$

where: $\mathrm{ED}_{\mathrm{us}}=$ elastic constant in ultrasonic tests $(\mathrm{MPa}) ; \mathrm{V}=$ velocity of wave propagation $\left(\mathrm{m} \mathrm{s}^{-1}\right)$; $\rho_{12 \%=}$ specific gravity at $12 \%$ moisture content $\left(\mathrm{kg} \mathrm{m}^{-3}\right)$.

The stress wave tests were performed in stress wave timer equipment (Metriguard, model 239A). The heartwood and sapwood samples were placed between two sensors with a span length of 140 $\mathrm{mm}$. The timer of the equipment was reset and the pendulum was liberated in order to obtain the time of wave propagation $(\mu \mathrm{s})$. Thus, the velocity of wave propagation $\left(\mathrm{m} \mathrm{s}^{-1}\right)$ and, consequently, the elastic constant in stress wave tests $\left(\mathrm{ED}_{\text {swt }}\right)$ were measured (Equation 2).

$E D_{s w t}=\frac{V^{2} \cdot \rho_{12 \%}}{A}$ where: $\mathrm{ED}_{\text {swt }}$ elastic constant in stress wave tests $(\mathrm{MPa}) ; \mathrm{V}=$ velocity of wave propagation $\left(\mathrm{m} \mathrm{s}^{-1}\right)$; $\rho_{12 \%}=$ specific gravity at $12 \%$ moisture content $\left(\mathrm{kg} \mathrm{m}^{-3}\right) ; \mathrm{A}=$ gravitational acceleration $\left(9.80 \mathrm{~m} \mathrm{~s}^{-2}\right)$.

\subsection{Destructive tests}

Destructive evaluation was carried out in a universal testing machine (EMIC, model DL-30000) with capacity of $300 \mathrm{kN}$. The static bending tests were performed in a three-point bending apparatus with a span length of $140 \mathrm{~mm}$ according to ASTM D143-94 (ASTM, 1997).

\subsection{Statistical analysis}

The data were assessed by analysis of variance $(p<0.05)$ and regression analysis. In the analysis of variance, when the null hypothesis was rejected, the mean values were compared by the Tukey test at 5\% significance level. The regression models were adjusted as a function of coefficient of determination $\left(\mathrm{R}^{2}\right)$, F-statistic, and mean absolute error (MAE). Moreover, a $p$-value of 0.05 (corresponding to $5 \%$ probability of error) was considered.

\section{RESULTS AND DISCUSSION}

Mean values of $\rho_{12 \%}$ of heartwood and sapwood were statistically different (Table 1). $\rho_{12 \%}$ of sapwood was $14.4 \%$ higher than $\rho_{12 \%}$ of heartwood.

Table 1. Mean values of physico-mechanical properties of Eucalyptus grandis wood.

Tabela 1. Valores médios das propriedades físico-mecânicas da madeira de Eucalyptus grandis.

\begin{tabular}{|c|c|c|c|}
\hline Property & Wood type & Mean & CV (\%) \\
\hline \multirow{2}{*}{$\rho_{12 \%}\left(\mathrm{~kg} \mathrm{~m}^{-3}\right)$} & Heartwood & $494 \mathbf{a}$ & 10.15 \\
\hline & Sapwood & $578 \mathbf{b}$ & 6.76 \\
\hline \multirow{2}{*}{$\operatorname{MOE}(\mathrm{MPa})$} & Heartwood & $11169.6 \mathbf{a}$ & 14.36 \\
\hline & Sapwood & $13021.6 \mathbf{b}$ & 17.79 \\
\hline \multirow{2}{*}{$\mathrm{V}_{\mathrm{us}}\left(\mathrm{m} \mathrm{s}^{-1}\right)$} & Heartwood & 5905.09 a & 6.26 \\
\hline & Sapwood & $5844.48 \mathbf{a}$ & 6.36 \\
\hline \multirow{2}{*}{$\mathrm{ED}_{\text {us }}(\mathrm{MPa})$} & Heartwood & $17384.6 \mathbf{a}$ & 19.54 \\
\hline & Sapwood & $20170.0 \mathbf{b}$ & 18.50 \\
\hline \multirow{2}{*}{$\mathrm{V}_{\mathrm{swt}}\left(\mathrm{m} \mathrm{s}^{-1}\right)$} & Heartwood & $3903.90 \mathrm{a}$ & 5.10 \\
\hline & Sapwood & $3958.44 \mathbf{a}$ & 5.68 \\
\hline \multirow{2}{*}{$\mathrm{ED}_{\text {swt }}(\mathrm{MPa})$} & Heartwood & $7722.4 \mathbf{b}$ & 15.39 \\
\hline & Sapwood & $9397.4 \mathbf{a}$ & 17.04 \\
\hline
\end{tabular}

$\rho_{12 \%}=$ specific gravity at $12 \%$ moisture content; $\mathrm{MOE}=$ modulus of elasticity in static bending tests; $\mathrm{V}_{\mathrm{us}}$ = ultrasonic velocity; $\mathrm{ED}_{\text {us }}=$ elastic constant in ultrasonic tests; $\mathrm{V}_{\text {swt }}=$ stress wave velocity; $\mathrm{ED}_{\text {swt }}=$ elastic constant in stress wave tests; $\mathrm{CV}=$ coefficient of variation. Mean values in the same column for each property followed by the same letter are not statistically different at level of $5 \%$ probability of error by the Tukey test. 
Poubel et al. (2011) reported values of specific gravity of heartwood lower than sapwood in Eucalyptus pellita. Specific gravity could vary as a function of anatomical characteristics, such as vessel proportion, thickness of fiber wall, and length, width and diameter of lumen (Panshin \& De Zeeuw, 1970).

The results of mechanical properties were statistically higher in sapwood than in heartwood.
The mean values of $\mathrm{MOE}, \mathrm{ED}_{\text {us }}$ and $\mathrm{ED}_{\text {swt }}$ of sapwood were $14.22,13.80$ and $17.82 \%$ higher than those of heartwood.

The mean value of $\mathrm{ED}_{\text {us }}$ in heartwood was $17384 \mathrm{MPa}$, which is similar to that found by Stangerlin et al. (2008) for the same species. On the other hand, the mean value of $\mathrm{ED}_{\text {swt }}$ in heartwood was 7722.4 MPa. Garcia et al. (2012), using the stress

\section{Heartwood}
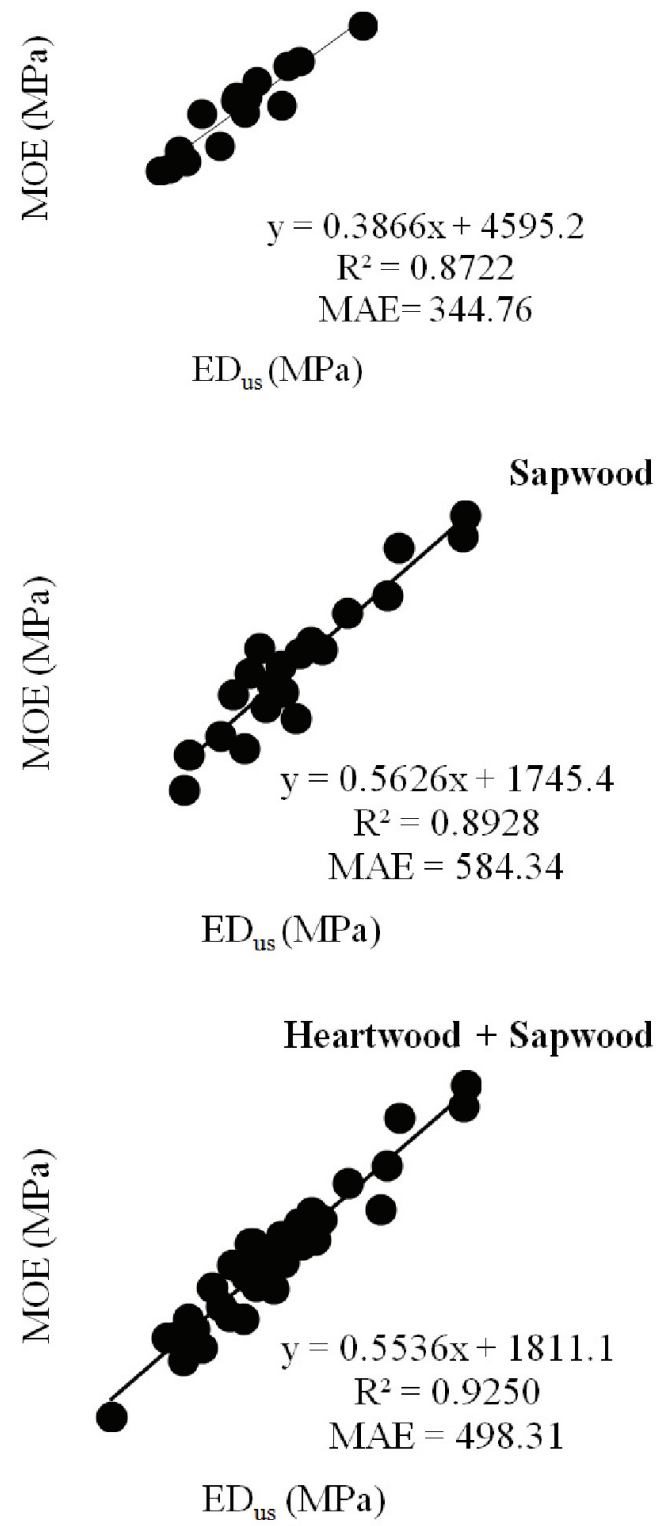
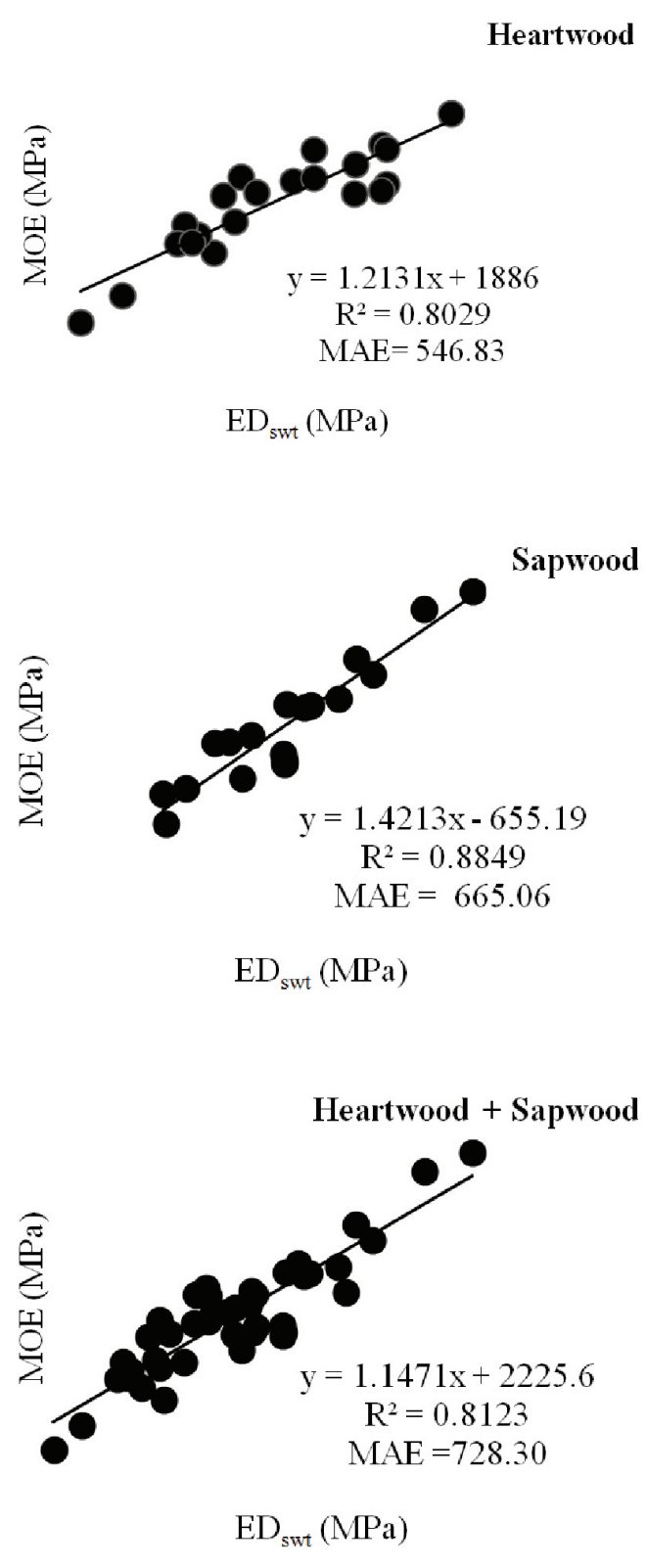

Figure 1. Mathematical models adjusted to $\mathrm{MOE}$ as a function of $\mathrm{ED}_{\mathrm{us}}$ and $\mathrm{ED}_{\text {swt }}$ of Eucalyptus grandis wood. Figura 1. Modelos matemáticos ajustados para o $\mathrm{MOE}$ em função do $\mathrm{ED}_{\text {us }}$ e $\mathrm{ED}_{\text {swt }}^{\text {swt }}$ da madeira de Eucalyptus grandis. 
wave technique, found $\mathrm{ED}_{\text {swt }}$ between 11166 and $12735 \mathrm{MPa}$. Considering that, $\mathrm{V}_{\text {us }}$ and $\mathrm{V}_{\text {swt }}$ did not present significant difference; it is possible to affirm that $\rho_{12 \%}$ had great influence on the nondestructive properties (see Equation 1). Oliveira \& Sales (2006) found a significant tendency between species for the increase of ultrasonic velocity as a function of specific gravity. However, analyses of the anatomical structure of wood are important to visualize changes in nondestructive properties, such as tracheid length and fiber length (Oliveira \& Sales, 2000).

Moreover, the mean values of ultrasonic tests overestimated MOE, while the mean values of stress wave tests underestimated $\mathrm{MOE} . \mathrm{ED}_{\text {us }}$ was 35.5 and $35.7 \%$ higher than in MOE for heartwood and sapwood, respectively. On the other hand, $\mathrm{ED}_{\text {swt }}$ was 30.9 and $27.8 \%$ lower than MOE. Cunha \& Matos (2010) also observed an underestimation of MOE after tests with stress wave timer $(\sim 50 \%)$ in glulam beam of Pinus taeda. Regarding overestimation of MOE by ultrasound tests, Miná et al. (2004), in Eucalyptus citriodora wood poles, and Stangerlin et al. (2010), in Peltophorum dubium wood, also verified this behavior.

This difference between mean values of modulus of elasticity obtained through nondestructive and destructive techniques was also observed in other studies using transversal vibration (Targa et al., 2005; Teles et al., 2011), ultrasound (Oliveira et al., 2002; Stangerlin et al., 2008; Vivian et al., 2012), resonance analysis (Leite et al., 2012), and stress wave (Ishiguri et al., 2008; Del Menezzi et al., 2010; Teles et al., 2011;).

The mathematical models adjusted for Rose gum heartwood and sapwood are shown in Figure 1.

Figure 1 shows that all models were significant at level of 5\% probability of error. All the models presented values of coefficient of determination between 0.80 and 0.93 , proving that more than $80 \%$ variation of MOE can be explained by the variation of $\mathrm{ED}_{\text {us }}$ or $\mathrm{ED}_{\text {swt }}$. The models created for heartwood showed $\mathrm{R}^{2}$ slightly lower than the models created for sapwood for both nondestructive techniques.

Other studies (Del Menezzi et al., 2010) investigated the relationship between MOE and $\mathrm{ED}_{\text {swt }}$ in six species, and found a coefficient of determination of 0.91 . According to the authors, the models showed low predictability for the same species when the variability was small. However, these reports differ from the present study, in which models with $\mathrm{R}^{2}>0.80$ were observed for the same species. Likewise, Oliveira et al. (2002) reported coefficients of determination of 0.63 and 0.59 in the relationship MOE versus $\mathrm{ED}_{\text {us }}$ for Goupia glabra and Hymenaea sp. wood, respectively.

All the mathematical models presented positive angular coefficients, which indicate a positive inclination of the tendency line. This fact confirms the hypothesis proposed by The Speed Sound (NDT, 2013). The authors affirmed that, if the elastic property is individually analyzed, materials with high elastic properties present high stiffness and proximity between molecules.

\section{CONCLUSIONS}

The use of nondestructive techniques for prediction of modulus of elasticity showed better behavior in heartwood compared with sapwood of Rose gum. However, the best model was obtained considering both wood types when analyzed through the ultrasonic technique.

The results obtained in the present study showed that stress wave and ultrasound techniques can be employed to predict the modulus of elasticity of Eucalyptus grandis wood.

\section{SUBMISSION STATUS}

Received: 06 May, 2013

Accepted: 02 Mar., 2014

Published: 28 Aug, 2014

\section{CORRESPONDENCE TO}

\section{André Luiz Missio}

Programa de Pós-Graduação em Engenharia Florestal - PPGEF, Centro de Ciências Rurais, Universidade Federal de Santa Maria - UFSM, CEP 97105-900, Santa Maria, RS, Brasil e-mail: andreluizmissio@gmail.com 


\section{REFERENCES}

American Society for Testing and Materials - ASTM. D143-94: Standards methods of testing small clear specimens of timber. Philadelphia: Annual Book of ASTM Standard; 1997. p. 23-53.

Brashaw BK, Bucur V, Divos F, Gonçalves R, Lu J, Meder R, et al. Nondestructive testing and evaluation of wood: aworldwide research update. Forest Products Journal 2009, 59(3): 7-14.

Carrasco EVM, Azevedo AP. Avaliação não destrutiva de propriedades mecânicas de madeiras através de ultrasom: fundamentos físicos e resultados experimentais. Cerne 2003, 9(2): 178-191.

Cunha AB, Matos JLM. Determinação do módulo de elasticidade em madeira laminada colada por meio de ensaio não destrutivo ("stress wave timer"). Revista Árvore 2010, 34(2): 345-354. http://dx.doi.org/10.1590/ S0100-67622010000200018

Del Menezzi CHS, Silveira RR, Souza MR. Estimativa das propriedades de flexão estática de seis espécies de madeiras amazônicas por meio da técnica não-destrutiva de ondas de tensão. Acta Amazônica 2010, 40(2): 325-332. http://dx.doi. org/10.1590/S0044-59672010000200011

Feeney FE, Chivers RC, Evertsen JA, Keating J. The influence of inhomogeneity on the propagation of ultrasound in wood. Ultrasonics 1998, 36(1),449-453. http://dx.doi.org/10.1016/S0041-624X(97)00066-8

Garcia R, Carvalho A, Figueiredo Latorraca J, Matos J, Santos W, et al. Nondestructive evaluation of heat-treated Eucalyptus grandis Hill ex Maiden wood using stress wave method. Wood Science and Technology 2012, 46(1),41-52. http://dx.doi. org/10.1007/s00226-010-0387-6

Gonçalez JC, Valle AT, Costa AF. Estimativas das constantes elásticas da madeira por meio de ondas ultra-sonoras (ultra-som). Cerne 2001, 7(1): 81-92.

Ishiguri F, Matsui R, Iizuka K, Yokota S, Yoshiza WAN. Prediction of the mechanical properties of lumber by stress-wave velocity and Pilodyn penetration of 36-year-old Japanese larch trees. European Journal of Wood and Wood Products 2008, 66(4): 275-280. http:// dx.doi.org/10.1007/s00107-008-0251-7

Leite ERDS, Hein PRG, Souza TMD, Rabelo GF. Estimation of the dynamic elastic properties of wood from Copaifera langsdorffii Desf using resonance analysis. Cerne 2012, 18(1): 41-47. http://dx.doi. org/10.1590/S0104-77602012000100006

Miná AJS, Dias AA, Calil Junior C. Avaliação da rigidez e da resistência de postes de madeira para uso como estacas para fundações. In: Anais do 9. Encontro
Brasileiro em Madeiras e em Estruturas de Madeira; 2004; Cuiabá. Cuiabá; 2004.

Missio AL, Gatto DA, Modes KS, Santini EJ, Stangerlin DM, Calegari L. Método ultrassônico para estimativa do módulo de elasticidade de madeiras de Pinus taeda tratadas termicamente. Ciência Rural 2013a; 43(4): 616-622. http://dx.doi.org/10.1590/ S0103-84782013000400009

Missio AL, Gatto DA, Modes KS, Santini EJ, Stangerlin DM, Calegari L. Ultrasonic method for estimation of modulus of elasticity of Eucalyptus grandis wood. Revista Brasileira de Ciências Agrárias 2013b; 8(1): 102-107. http://dx.doi.org/10.5039/agraria.v8ila1872

Nondestructive Techniques Resource Center - NDT. The speed of sound in other materials. [cited 2013 Jan 21]. Available from: http://www.ndt-ed.org/ EducationResources/HighSchool/Sound/hs_sound_ index.htm.

Oliveira FGR, Campos JAOD, Sales A. Ultrasonic measurements in Brazilian Hardwood. Materials Research 2002, 5(1): 51-55. http://dx.doi.org/10.1590/ S1516-14392002000100009

Oliveira FGR, Sales A. Propagação de ondas acústicas na madeira. In: Encontro brasileiro em madeiras $e$ estruturas de madeiras; 2000; São Carlos. São Paulo: Instituto Brasileiro da Madeira e das Estruturas de Madeira; 2000

Oliveira FGR, Sales A. Relationship between density and ultrasonic velocity in Brazilian tropical woods. Bioresource Technology 2006, 97(18): 24432446. PMid:16311030. http://dx.doi.org/10.1016/j. biortech.2005.04.050

Panshin AJ, De Zeeuw C. Textbook of wood technology. New York: McGraw-Hill; 1970.

Pellerin RF, Ross JR. Nondestructive evaluation of wood. Madison: Forest Products Society; 2002.

Poubel DDS, Garcia RA, Latorraca JVDF, Carvalho AMD. Estrutura anatômica e propriedades físicas da madeira de Eucalyptus pellita F. Muell. Floresta e Ambiente 2011, 18(2): 117-126. http://dx.doi. org/10.4322/floram.2011.029

Ross RJ, Brashaw BK, Pellerin RF. Nondestructively evaluation of wood. Forest Products Journal 1998, 48(1): 14-19.

Ross RJ, Pellerin RF. Nondestructive testing for assessing wood members in structures. Madison: U.S. Department of Agriculture, Forest Service, Forest Products Laboratory; 1994.

Stangerlin DM, Calegari L, Santini EJ, Domingues JMX, Gatto DA, Melo RR. Determinação do módulo de elasticidade em madeiras por meio de métodos destrutivo e não-destrutivo. Revista Brasileira de 
Ciências Agrárias 2008, 3(2): 145-150. http://dx.doi. org/10.5039/agraria.v3i2a284

Stangerlin DM, Gatto DA, Melo RR, Calegari L, Vivian MA, Castelo PAR, et al. Uso do ultrassom para estimativa das propriedades mecânicas da madeira de Peltophorum dubium. Ciência da Madeira 2010, 1(2): 44-53. http:// dx.doi.org/10.12953/2177-6830.v01n02a04

Targa LA, Ballarin AW, Biaggioni MAM. Avaliação do módulo de elasticidade da madeira com uso de método não-destrutivo de vibração transversal. Engenharia Agrícola 2005, 25(2): 291-299. http://dx.doi. org/10.1590/S0100-69162005000200001

Teles RF, Del Menezzi CS, Souza F, Souza MR. Nondestructive evaluation of a tropical hardwood: interrelationship between methods and physicalacoustical variables. Ciência da Madeira 2011, 2(1): 1-14. http://dx.doi.org/10.12953/2177-6830.v02n01a01

Vivian MA, Santini EJ, Modes KS, Carvalho DE, Morais WWC, Souza JTD, et al. Estimativa da resistência e rigidez da madeira de Eucalyptus grandis por meio de onda ultrassonora. Pesquisa Florestal Brasileira 2012, 32(69),109-113. http://dx.doi. org/10.4336/2012.pfb.32.69.109

Wang X, Divos F, Pilon C, Brashaw BK, Ross RJ, Pellerin RF.Assessment of decay in standing timber using stress wave timing nondestructive evaluation tools. A guide for use and interpretation. Madison: U.S. Department of Agriculture, Forest Service, Forest Products Laboratory; 2004. 